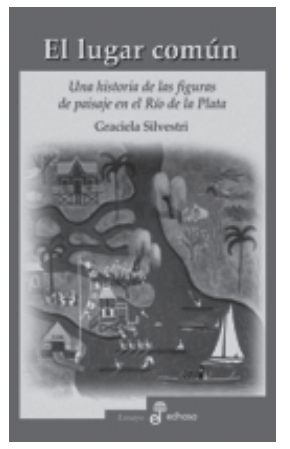

\title{
Graciela Silvestri. El lugar común. Una historia de las figuras de paisaje en el Río de la Plata.
}

\author{
Buenos Aires: Edhasa, 2011. 409 p.
}

\author{
Andrés Núñez
}

Los estudios culturales tienen la virtud de alejarse de una comprensión lineal de la historia, es decir, de aquel tipo de historia de sentido evolutivo, de base hegeliana. Por el contrario, nuevas investigaciones asientan sus bases en un aspecto que resulta crucial: comprender que el conocimiento surge en un contexto finito y que, por lo mismo, como ha expuesto Foucault (1997), ese saber se aferra a formaciones discursivas que poseen un principio y un fin en sí mismo. Este vital aspecto, desde nuestro punto de vista, permite visualizar, por ejemplo, que determinada representación o imagen de un país es un constructo social y cultural que es identificable temporalmente y que permite ponderar aquella construcción desde un enunciado -ya no de un sujeto- que la piensa y practica. El libro de la Arquitecta y Dra. en Historia Graciela Silvestri se encamina sin duda en ese derrotero. Dice ella: "El privilegio que otorgo en este libro a las imágenes no significa, por cierto, aislarlas de la trama discursiva en la que adquieren sentido" (p. 18).

El otro aspecto que parece importante al momento de analizar el libro El lugar común es que a través de él es posible comprender que el espacio es el resultado de prácticas que le van configurando sentidos y significados. Desde esta posición, la noción de espacio, como muy bien expone Silvestri, deviene en paisaje, en tanto saber constituido, en tanto espacio simbólico fundado desde una estética temporalmente tan finita como dinámica (tal vez por lo mismo).

\footnotetext{
1 Instituto de Geografía, Pontificia Universidad Católica de Chile (Chile).E-mail: aanunezg@uc.cl
}

En este contexto, preguntarse como lo hace Silvestri sobre ¿cómo nos formamos la imagen territorial de un país?, es cuestionarse, como lo hizo Bourdieu (1988), respecto de si es factible trabajar determinadas espacialidades sin preguntarse cómo y bajo qué lógicas se van definiendo. Es decir, abordar el problema bajo la siguiente pregunta estructural: ¿es posible visualizar una espacialidadpaís sin intentar comprender la convención histórico-cultural que la proyecta o la ha proyectado?

Silvestri, en ese sentido, desarrolla un trabajo tan erudito como bello, al enfrentarnos a un proceso -o a una historia- que va deconstruyendo la producción de la "cultura identitaria" de la nación argentina. Desde esta perspectiva, las imágenes, las figuras, los relatos, analizados en su obra a través de mapas, iconografías, itinerarios, lecciones de geografía, proyectos arquitectónicos, militares e ingenieriles, postales turísticas, entre otros, actúan como dispositivos que van forjando un modo de comprender el país, que fabrican un imaginario geográfico que termina por definirlo, orientarlo, enmarcarlo, en definitiva, racionalizarlo o, como diría Foucault, normalizarlo. Y esos mecanismos, finalmente, como lo indica el título del libro, lleva a que ese espacio-nación se transforme en "un lugar común" que termina siendo comunidad y espacio físico compartido: "El calificativo de común significa que no siendo privativo de ninguno pertenece a todos: introduce el espacio público, el espacio que nos reúne, la acción conjunta; una idea amplia, multiescalar, mezclada y transregional de patria (p. 24). 
En tal sentido, la plataforma investigativa del trabajo de Silvestri evita caer en una naturalización del espacio-nación de Argentina, es decir, en la concepción de un territorio objetivo, que le pertenece a la nación "desde siempre", para, por el contrario, resaltar que aquella espacialidad es el resultado, como dice Cosgrove, "de la expresión geográfica de identidades sociales y culturales" (2002), es decir, como la propia autora subraya, que surge desde "su radical historicidad" (p. 24).

Si bien el abordaje de la investigación es válido para proyectar el imaginario a escala nacional, Silvestri concentra su atención en el Río de la Plata, amplia zona donde se instala Buenos Aires, y no únicamente porque durante el siglo XIX aquel lugar fuese el puerto comercial por excelencia del vasto territorio interior sino básicamente, en coherencia con su propuesta en el ámbito de los estudios culturales, porque esa zona actuó como organizadora de los discursos-nación, es decir, como el marco contextual desde donde surgió el texto de la nación. Expresado de otro modo, funcionó como lugar jerárquico de la producción discursiva que liga el paisaje con la patria: "Es en el Río de la Plata donde se encarnan las posibilidades y los límites de la utopía proyectada sobre el espacio "vacío", edificada a través de las palabras" (p. 27). Una República a la que había que inventarle un futuro reconstruyendo un pasado desde la fijación de sentido de una, como dice Silvestri de forma aguda, segunda naturaleza. Claro, la naturaleza estaba allí como bien disponible, pero había que proyectar otra que reflejase aquel nuevo relato de la nación. Un paisaje protagonista en el libro de aquella segunda naturaleza o "lenguaje nacional" (p. 243) es la pampa, antes vacía y solitaria, luego sublime y atractiva: "Claro que esta naturaleza pampeana no es otra cosa que una construcción intelectual, un paisaje creado por la palabra" (p. 293). Porque, expresa Silvestri la "nueva pampa podrá no ser real, pero sí verosímil" (p. 246). Pero la pampa no el único ícono patrio. También lo son la Puna; los Andes mendocinos; las cataratas del Iguazú; los lagos del Sur (p. 336-337).

Aquel relato nacional, trabajado en forma magistral por Silvestri, tiene su origen en el siglo XVIII, cuando los procesos de racionalización del espacio inician su curso. Así hacia fines del siglo XVIII, por ejemplo, el viajero Malaspina en su paso por Buenos Aires, a través de pintores y dibujantes, articulaba belleza y verdad, buscando reflejar la perfección de la naturaleza. De ello da cuenta la autora en un primer capítulo titulado precisamente "Belleza Natural". Sin embargo, aquella convención sobre una belleza que define el paisaje de fines del siglo del XVIII y la primera mitad del XIX da paso a la necesidad de Ilevar al extremo los cuadros de la nación. Así, a la armonía, al equilibrio anterior irrumpe lo sublime, que todo lo exagera y que ahora nos remite a la "naturaleza en sus manifestaciones extraordinarias", nueva naturaleza que sustenta un sentimiento patrio que va configurando el paisaje de la nación. Así como en Chile la nación se construyó sobre una cordillera de los Andes excelsa, siempre nevada, siempre imponente, denotando el margen y resguardo de un hogar, así en la Argentina trabajada por Silvestri, las elocuencias de las imágenes -el desierto inconmensurable, los horizontes infinitos, las cataratas furiosas, los imponentes lagos, y una valorización, aunque tardía, vivaz de la pampa- van cicatrizando y afianzando un panorama expresivo que dibuja las huellas de la nueva nación, fijando una convención, un lugar común en torno a un paisaje que se afianza en los ojos culturales de la época. De este modo, lo sublime de la pampa, de las cataratas, de los desiertos, se transforman en "la" naturaleza de la nueva Argentina. Como titula el segundo capítulo, La oscilación de la sensibilidad, el siglo XIX da paso a la invención de aquel paisaje majestuoso llamado nación.

Aquel acuerdo cultural nos dice Silvestri, va adquiriendo el rango de "paisajes nacionales". Este lenguaje patriótico termina por madurar en la primera mitad del siglo XX, en una suerte de "destino de la patria", título del tercer capítulo del libro. De este modo, imagen y sentido de nación se entrelazan en una investigación que, como fue expresado, resalta el proceso de producción de la identidad nacional. Es decir, estamos frente a un trabajo que va en búsqueda de la sociogénesis de aquella identidad.

¿Cómo los paisajes adquieren el rasgo de nacionales?, ¿en qué momento y de qué modo aquel paisaje deviene en paisaje patrio? son cuestiones que Silvestri aborda a lo 
largo de todo el trabajo. En el fondo, es una investigación de desenmascaramiento de discursos socioculturales que fijaron en la patria, en la nación, un horizonte geográfico que se transformó en lugar común.

Sin duda, se trata de un libro indispensable para todos los interesados en visualizar los procesos de producción del espacio, de construcción de sus imaginarios geográficos $\mathrm{y}$, a su vez, para comprender los íconos a través de los cuales las imágenes, los paisajes se tornan verdaderos para una comunidad, en este caso para la sociedad argentina.

\section{Referencias bibliográficas}

BOURDIEU, P. Cosas dichas. Buenos Aires: Gedisa, 1988.

COSGROVE, D. Observando la naturaleza: el paisaje y el sentido europeo de la vista. Boletín de la A.G.E., 2002, № 34, p. 63-89.

FOUCAULT, M. La arqueología del saber. México: Siglo Veintiuno Editores, 1997. 
